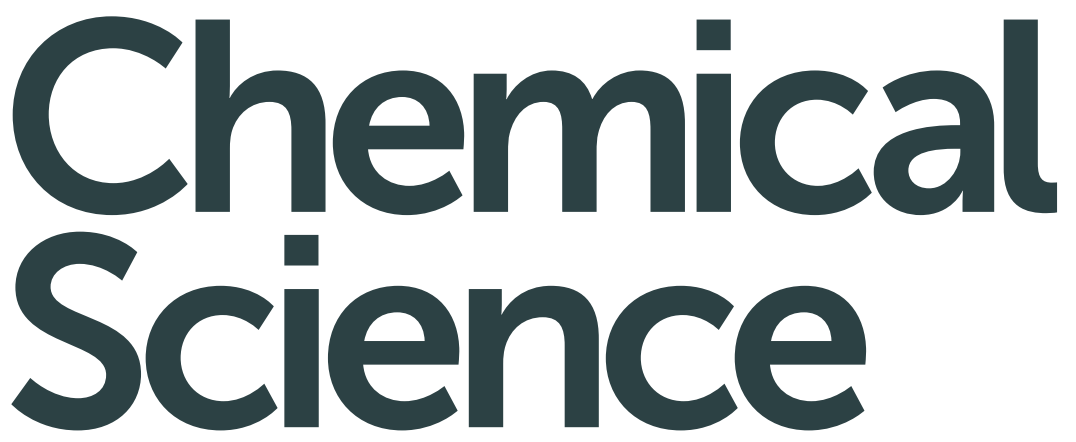

www.rsc.org/chemicalscience

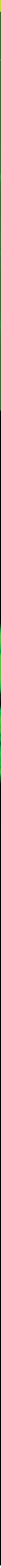

ISSN 2041-6520

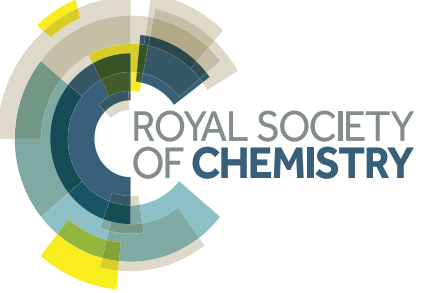




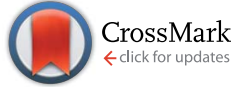

Cite this: Chem. Sci., 2014, 5, 3368

\title{
A water-soluble boronate-based fluorescent probe for the selective detection of peroxynitrite and imaging in living cells $\uparrow$
}

\author{
Xiaolong Sun, ${ }^{a}$ Qingling Xu, ${ }^{b}$ Gyoungmi Kim, ${ }^{b}$ Stephen E. Flower, ${ }^{a}$ John P. Lowe, ${ }^{a}$

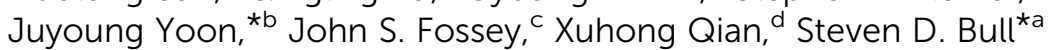 \\ and Tony D. James ${ }^{\star a}$
}

A water-soluble boronate-based fluorescent probe was evaluated for the detection of peroxynitrite $\left(\mathrm{ONOO}^{-}\right)$in the presence of a monosaccharide. The enhanced fluorescence of the probe when bound with $\mathrm{D}$-fructose was switched off in the presence of peroxynitrite. In contrast, other reactive oxygen/ nitrogen species (ROS/RNS) led to only slight fluorescence decreases due to protection by an internal $\mathrm{N}-\mathrm{B}$ interaction. The interaction of the probe with $\mathrm{D}$-fructose not only strengthens the fluorescence signal, but also protects the boronic acid from oxidation by other ROS/RNS. Therefore, under conditions generating various ROS/RNS, the boronate-based saccharide complex preferentially reacts with peroxynitrite. The probe was used in cell imaging experiments for the detection of endogenous and exogenous peroxynitrite. The sensor displays good "on-off" responses towards peroxynitrite, both in RAW 264.7 cells and HeLa cells.

Received 14th May 2014

Accepted 21st May 2014

DOI: $10.1039 / \mathrm{c} 4 \mathrm{sc} 01417 \mathrm{k}$

www.rsc.org/chemicalscience

Synthetic fluorescent probes have the potential to be

\section{Introduction}

Peroxynitrite $\left(\mathrm{ONOO}^{-}\right)$- a combination of nitric oxide and the superoxide radical anion - has been recognized as a strong oxidant in physiological and pathological processes. It was first discovered as a biological endogenous oxidant in $1990 .{ }^{1}$ Under physiological conditions, peroxynitrite is also a highly reactive molecule with a very short life time ( $\sim 10 \mathrm{~ms})$ involved in cell signal transduction ${ }^{2}$ and apoptosis in HL-60 cells, ${ }^{3}$ and PC-12 cells. ${ }^{4}$ Many biomolecules are oxidised and/or nitrated by peroxynitrite-derived radicals, including DNA, tyrosine residues, thiols, and unsaturated fatty-acid-containing phospholipids. ${ }^{5}$ Peroxynitrite formation has been implicated in Alzheimer's disease, Parkinson's disease, Huntington's disease, and traumatic brain injury. ${ }^{6-8}$ Recently, peroxynitrite was found as a key trigger of skeletal muscle hypertrophy via activation of calcium signaling. ${ }^{9}$ Thus, the importance of peroxynitrite has led to researchers seeking effective and applicable approaches for its detection.

${ }^{a}$ Department of Chemistry, University of Bath, Bath, BA2 7AY, UK. E-mail: s.d.bull@ bath.ac.uk; t.d.james@bath.ac.uk

${ }^{b}$ Department of Chemistry and Nano Science, Global Top 5 Program, Ewha Womans University, Seoul 120-750, Korea.E-mail: jyoon@ewha.ac.kr

'School of Chemistry, University of Birmingham, Birmingham, Edgbaston, West Midlands, B15 2TT, UK

${ }^{d}$ School of Pharmacy, East China University of Science and Technology, Meilong Road 130, Shanghai 200237, China

† Electronic supplementary information (ESI) available. See DOI: 10.1039/c4sc01417k powerful tools for peroxynitrite detection since they can measure intracellular $\mathrm{ONOO}^{-}$directly. ${ }^{10}$ Working towards the fluorescence detection of peroxynitrite, Yang et al. developed a range of chemo-sensors in which $\mathrm{ONOO}^{-}$reacts with activated ketones to form dioxiranes, ${ }^{\mathbf{1 1}-13}$ and Yang and Qian have also designed a three-channel fluorescent probe capable of distinguishing peroxynitrite from hypochlorite. ${ }^{14}$ Recently, Ai et al. reported a genetically encoded fluorescent probe for the detection of peroxynitrite. ${ }^{15}$ However, it still remains a great challenge to use small-molecular fluorescent probes to detect $\mathrm{ONOO}^{-}$selectively and sensitively amongst the large number of biologically relevant reactive oxygen and nitrogen species (e.g. $\mathrm{H}_{2} \mathrm{O}_{2}$ and $\mathrm{ClO}^{-}$).

We have a long-standing interest in boronic acids for monosaccharide and anion detection, ${ }^{\mathbf{1 6}-18}$ and have found that boronic acid derivatives rapidly and reversibly interact with saccharides in aqueous media. In previous work, we investigated the reaction of "integrated" and "insulated" boronatebased fluorescent probes with hydrogen peroxide $\left(\mathrm{p} K_{\mathrm{a}}=11.6\right)$ in the presence of monosaccharides. ${ }^{19}$ Chang and co-workers have also developed a series of boronate-based derivatives for the fluorescence detection of $\mathrm{H}_{2} \mathrm{O}_{2}$ in living systems. ${ }^{\mathbf{2 0 - 3 0}}$

Functional $N$-substituted-1,8-naphthalimide derivatives have been successfully employed as DNA targeting, anticancer and cellular imaging agents. ${ }^{31,32}$ Due to its excellent photophysical and photochemical properties, $N$-substituted-1,8naphthalimide is widely used as a D- $\pi-\mathrm{A}$ chromophore in the design of fluorescent probes. ${ }^{33,34}$ 
From our previous research, we found that boronic ester formation causes an enhanced interaction between the neighboring amine and the boron atom. The enhanced $\mathrm{N}-\mathrm{B}$ interaction $^{35}$ (whether direct or via solvent insertion) hinders the reaction between boron and $\mathrm{H}_{2} \mathrm{O}_{2}$ in the presence of saccharides resulting in a much slower decrease in fluorescence intensity ( $c f$. a saccharide free system).

It is known that $\mathrm{ONOO}^{-}\left(\mathrm{p} K_{\mathrm{a}}=6.8\right)-$ a strong nucleophile reacts rapidly and stoichiometrically with aromatic boronate derivatives $\left(\kappa \sim 10^{6} \mathrm{M}^{-1} \mathrm{~S}^{-1}\right.$ at $\mathrm{pH} 7.4$, Scheme 1$) .{ }^{36-38}$ From this observation and our previous results, we wondered if a powerful nucleophile such as $\mathrm{ONOO}^{-}$could overcome the protection given to the boron atom by the $\mathrm{N}-\mathrm{B}$ interaction in the "insulated" probes. Therefore, we reasoned that it would be possible to develop boronate-based "insulated" probes for the selective intracellular mapping of peroxynitrite in the presence of a monosaccharide (D-fructose was chosen as a model saccharide since it has a high binding affinity, $\left.\sim 4400 \mathrm{~mol}^{-1}\right) .{ }^{18}$

\section{Results and discussion}

\section{Design strategy}

Probe $1\left(\lambda_{\mathrm{abs}}=440 \mathrm{~nm}, \varepsilon=9500 \mathrm{M}^{-1} \mathrm{~cm}^{-1}\right.$, Scheme 2) was designed based on a PET fluorescence mechanism, with the introduction of hydroxyethoxyl side chain to not only improve the water-solubility, but also to provide a potential route to develop a polymer bound receptor. Probe $\mathbf{1}$ was synthesised in three steps starting from 4-bromo-1,8-naphthalic anhydride in $24 \%$ overall yield (Scheme $\mathrm{S} 1 \dagger$ ). ${ }^{39}$ The boronic acid moiety is widely recognized as an excellent binding node through which to connect a monosaccharide with the fluorescent probe. The "insulated" system displays an "off-on" response towards Dfructose due to the enhanced $\mathrm{N}-\mathrm{B}$ interaction (Scheme 2). ${ }^{\mathbf{4 0}}$ Furthermore, we decided to evaluate the fluorescence properties of the monosaccharide complex towards peroxynitrite in vitro and also using in vivo cellular imaging for endogenous and exogenous derived peroxynitrite.

We carried out a $\mathrm{pH}$ titration to evaluate the effect of $\mathrm{pH}$ on the fluorescence of probe $1(2 \mu \mathrm{M})$. As shown by Fig. 1, the fluorescence intensity of the probe $\mathbf{1}$ decreased at $\mathrm{pH}$ values above 8.0, while in the range between 3.0 and 8.0 , the $\mathrm{pH}$ change had minimal effect on the fluorescence intensity. Thus, the probe can be expected to work well under physiological conditions ( $\mathrm{pH} 7.30, \mathrm{PBS}$ buffer). In the presence of $\mathrm{D}$-fructose (100 $\mathrm{mM})$, the fluorescence of the formed 1-D-fructose complex increases due to the enhanced $\mathrm{N}-\mathrm{B}$ interaction at different $\mathrm{pH}$ values. The fluorescence of the 1-D-fructose complex decreases over a $\mathrm{pH}$ range of $3-11$.

\section{UV-Vis and emission spectra towards $\mathrm{ONOO}^{-}$}

In the case of probe 1, a significant "off-on" signal response is seen on binding with D-fructose due to inhibition of the PET mechanism. From Fig. 2a, the maximum fluorescence intensity of probe $1\left(2 \mu \mathrm{M}, \lambda_{\mathrm{em}}=525 \mathrm{~nm}\right)$ is increased two-fold in the presence of $\mathrm{D}$-fructose $(100 \mathrm{mM})$ in $\mathrm{pH} 7.3$ buffer solution. However, when the arylboronic ester moiety of probe 1 was transformed into a phenol upon adding peroxynitrite, the fluorescence was further reduced due to the stronger PET from the amine in the boron free system. As can be seen from the dose-dependent titration curve in Fig. 2b, the enhanced fluorescence of the probe $1-\mathrm{D}$-fructose complex was finally reduced to a $F$ (in the presence of $\left.\mathrm{ONOO}^{-}\right) / F_{0}$ (in the absence of $\mathrm{ONOO}^{-}$) $=c a$. 0.10 over a $\mathrm{ONOO}^{-}$concentration range of 0-297 $\mu \mathrm{M}$. In contrast, for the saccharide free system small amounts of peroxynitrite $(60 \mu \mathrm{M})$ caused a big change in fluorescence intensity $\left(F / F_{0}=c a\right.$. 0.10, Fig. $2 \mathrm{c}$ and d). In the UV-Vis spectra (Fig. S2 $\dagger$ ), the free boronic acid probe $1(2 \mu \mathrm{M})$ displayed a maximum absorption $(A=0.026)$ at $440 \mathrm{~nm}$ while the binding of $\mathrm{D}$-fructose (100 $\mathrm{mM}$ ) led to a decrease to $A=0.019$ at the maximum absorption wavelength. In the presence of $\mathrm{ONOO}^{-}(100 \mu \mathrm{M})$, a new peak $(A=0.021)$ at $360 \mathrm{~nm}$ developed, ascribable to the formation of phenol.

Thus, the fluorescence of probe $\mathbf{1}$ is turned on by saccharide binding, since boronic ester formation causes an enhanced interaction between the neighbouring amine and the boron atom.

\section{Emission spectra towards $\mathrm{H}_{2} \mathrm{O}_{2}$}

Since boronate-based derivatives can be oxidised to phenol by $\mathrm{H}_{2} \mathrm{O}_{2}$ and $\mathrm{ONOO}^{-}$, it is very important to discriminate between them by fluorescence tools. Independently, we tested the responses of probe $\mathbf{1}$ and the 1-D-fructose complex towards hydrogen peroxide (Fig. 3 and $\mathrm{S} 4 \dagger$ ). With the free boronic acid system, the fluorescence of probe $1(2 \mu \mathrm{M})$ increased to $F / F_{0}=c a .1 .59$ in the presence of hydrogen peroxide $(100 \mu \mathrm{M})$ over $1 \mathrm{~h}$ in $\mathrm{pH} 7.30$ buffer solution (Fig. S4†). When the solution was adjusted to $\mathrm{pH} 8.10$, the fluorescence decreased most probably due to the decomposition of the intermediate to phenol (Fig. 3a). This is different from the process observed for the detection of $\mathrm{ONOO}^{-}$in which the boronic acid was transformed into phenol quickly and directly. However, in the case of the 1-D-fructose complex the fluorescence showed only a slight drop to $F / F_{0}=c a$. 0.75, even after the addition of $\mathrm{H}_{2} \mathrm{O}_{2}(1 \mathrm{mM})$ over $1 \mathrm{~h}$ (Fig. $3 \mathrm{~b}$ and $\mathrm{S} 7 \dagger)$. Therefore, the probe 1-D-fructose complex does not produce a significant response to $\mathrm{H}_{2} \mathrm{O}_{2}$.

Thus, the interaction of probe 1 with $\mathrm{D}$-fructose not only strengthens the fluorescence signal, but also protects the

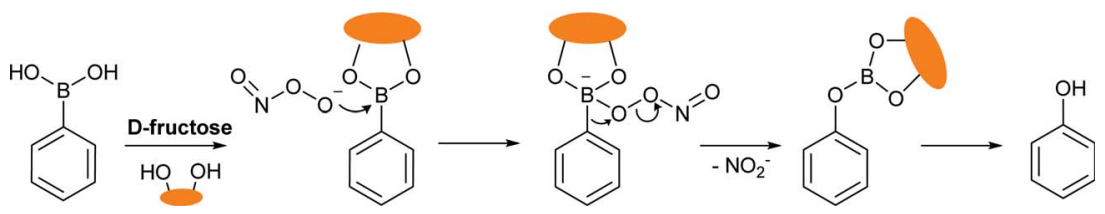

Scheme 1 The reaction mechanism between a generic aryl boronic acid/ester and $\mathrm{ONOO}^{-}$. 

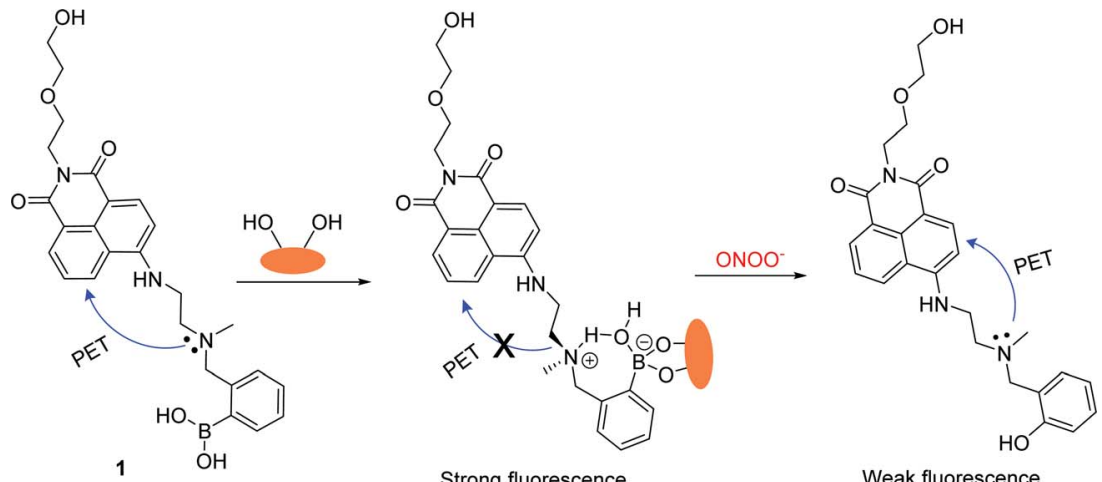

Scheme 2 Design strategy of probe 1 for the detection of peroxynitrite in the presence of $D$-fructose.

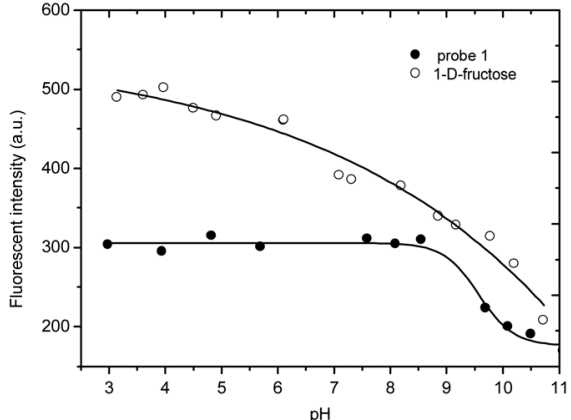

Fig. $1 \mathrm{pH}$ titration of probe $1(2 \mu \mathrm{M})$ and 1-D-fructose (probe 1, $2 \mu \mathrm{M}$ $\mathrm{D}$-fructose, $100 \mathrm{mM}$ ), modulated by utilizing aqueous hydrochloric acid $(1.2 \mathrm{~N})$ and sodium hydroxide solution $(1 \mathrm{~N})$.

boronic acid from oxidation by hydrogen peroxide via the N-B interaction. However, the oxidation reaction between boron and peroxynitrite was still very rapid and was complete within $1 \mathrm{~min}$ (Fig. S3†).

The sugar complex reacts stoichiometrically and rapidly with $\mathrm{ONOO}^{-}$to form the phenol product. Therefore, under
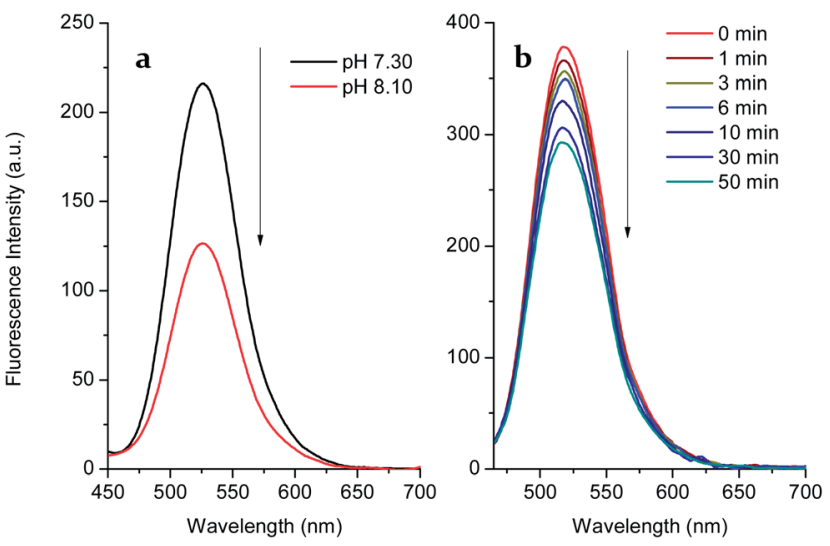

Fig. 3 (a) Fluorescence spectra of probe 1 after reaction with $\mathrm{H}_{2} \mathrm{O}_{2}$ at $\mathrm{pH} 7.30$ and $\mathrm{pH} 8.10$. The $\mathrm{pH}$ was adjusted from 7.30 to 8.10 using aqueous sodium hydroxide $(10 \mathrm{~N})$; (b) fluorescence spectra of the probe 1-D-fructose complex (probe 1, $2 \mu \mathrm{M}$; D-fructose, $100 \mathrm{mM}$ ) in the presence of hydrogen peroxide $(1 \mathrm{mM})$ at $\mathrm{pH} 7.3$ buffer solution. The spectra were collected at different times with excitation at $410 \mathrm{~nm}$ (Ex slit: 5.0, Em slit: 5.0).
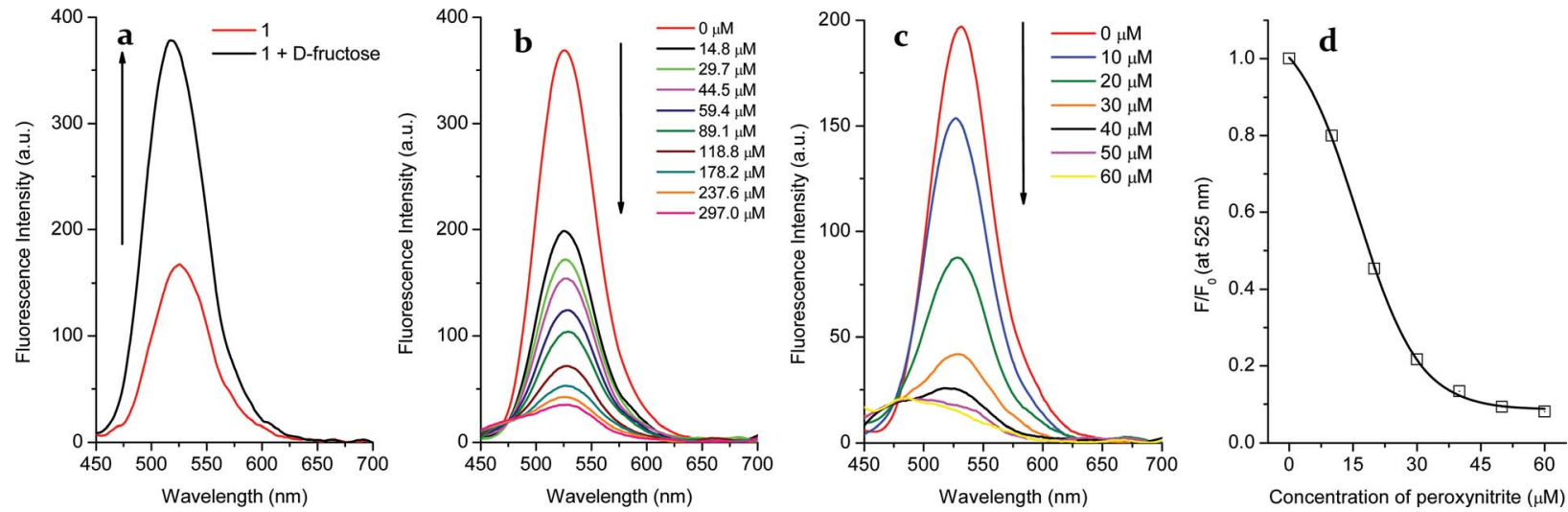

Fig. 2 (a) Fluorescence spectra of probe $1(2 \mu \mathrm{M})$ before and after the addition of $D$-fructose $(100 \mathrm{mM})$. After the addition of $\mathrm{D}$-fructose, the mixtures were stirred for $10 \mathrm{~min}$; (b) probe 1-D-fructose complex (probe 1, $2 \mu \mathrm{M}$; D-fructose, $100 \mathrm{mM}$ ) at different concentrations of ONOO ${ }^{-}$. After addition of peroxynitrite, the mixtures were stirred for $5 \mathrm{~min}$; (c) fluorescence spectra of probe 1 ( $2 \mu \mathrm{M})$ in the presence of various concentrations of peroxynitrite in $\mathrm{pH} 7.3$ buffer solution; (d) the non-linear relationship between probe $1(2 \mu \mathrm{M})$ and $\mathrm{ONOO}^{-}(0-60 \mu \mathrm{M})$ in pH 7.3 buffer solution. The spectra were collected after 5 min stirring for each dose. The data were collected in PBS buffer (1/15 M, pH 7.30) with excitation at $410 \mathrm{~nm}$ (Ex slit: $5 \mathrm{~nm}$, Em slit: $5 \mathrm{~nm}$ ). 
conditions generating both $\mathrm{H}_{2} \mathrm{O}_{2}$ and $\mathrm{ONOO}^{-}$, the probe 1-Dfructose complex preferentially reacts with $\mathrm{ONOO}^{-}$.

\section{Selectivity tests towards ROS/RNS}

We also investigated the selectivity of the 1-D-fructose complex towards other reactive oxygen and nitrogen species, such as hypochlorite $\left({ }^{-} \mathrm{OCl}\right)$, nitric oxide ( $\left.\mathrm{NO}\right)$, nitrite $\left(\mathrm{NO}_{2}{ }^{-}\right)$, nitrate $\left(\mathrm{NO}_{3}{ }^{-}\right)$, peroxyl radicals ( $\left.\mathrm{ROO}{ }^{\circ}\right)$, superoxide $\left(\mathrm{O}_{2}{ }^{-}\right)$and hydroxyl radicals $\left({ }^{\circ} \mathrm{OH}\right)$ in $\mathrm{pH} 7.30$ buffer solution (Fig. 4 and $\mathrm{S} 8 \dagger$ ). Among them, only hypochlorite $(100 \mu \mathrm{M})$ caused a big fluorescence decrease $\left(\left(F-F_{0}\right) / F=c a\right.$. 0.52) (Fig. 4b). As reported previously, ${ }^{37}$ aryl boronic acids and esters can be oxidised into phenol by hypochlorite. However, under the same concentrations of ${ }^{-} \mathrm{OCl}(100 \mu \mathrm{M})$ and $\mathrm{ONOO}^{-}(100 \mu \mathrm{M})$, peroxynitrite reacts much more strongly with the $1-\mathrm{D}$-fructose sensing system $\left(\left(F-F_{0}\right) / F=c a\right.$. 0.78).

We also tested the fluorescence reaction of the 1-D-fructose complex towards $\mathrm{ONOO}^{-}$and $\mathrm{H}_{2} \mathrm{O}_{2}$ in pH 5.0 buffer solution in order to mimic the acidic conditions found in cancer cells (Fig. S9 $\dagger$ ). Under the same concentrations of $\mathrm{H}_{2} \mathrm{O}_{2}(500 \mu \mathrm{M})$ and
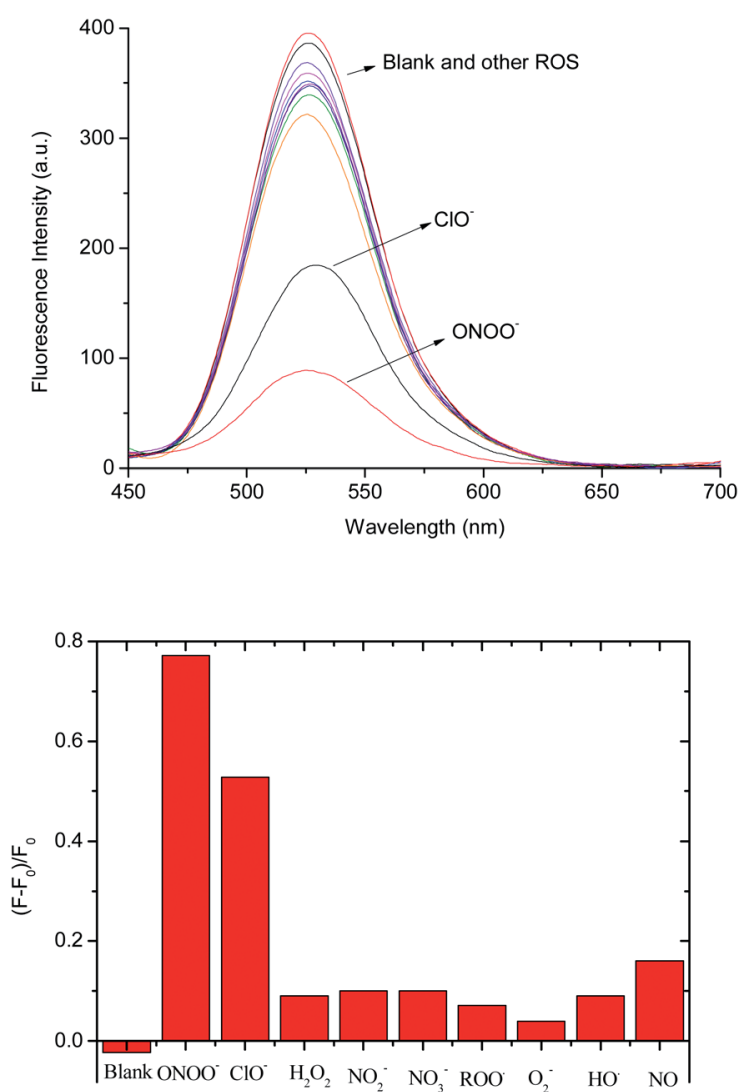

Fig. 4 (a) Fluorescence spectra of probe 1-D-fructose (probe 1, $2 \mu \mathrm{M}$; $\mathrm{D}$-fructose, $100 \mathrm{mM})$ in the presence of various ROS/RNS: ONOO(100 $\mu \mathrm{M}, 5 \mathrm{~min}),{ }^{-} \mathrm{OCl}(100 \mu \mathrm{M}, 5 \mathrm{~min}), \mathrm{H}_{2} \mathrm{O}_{2}(100 \mu \mathrm{M}, 5 \mathrm{~min}), \mathrm{NO}_{2}{ }^{-}$ (100 $\mu \mathrm{M}, 5 \mathrm{~min}), \mathrm{NO}_{3}{ }^{-}(100 \mu \mathrm{M}, 5 \mathrm{~min}), \mathrm{ROO} \cdot(100 \mu \mathrm{M}, 5 \mathrm{~min}),{ }^{\circ} \mathrm{O}_{2}{ }^{-}$ $(100 \mu \mathrm{M}, 5 \mathrm{~min}), \mathrm{OH}(100 \mu \mathrm{M}, 5 \mathrm{~min})$ and $\mathrm{NO}(100 \mu \mathrm{M}, 5 \mathrm{~min})$ in $\mathrm{pH}$ 7.30 buffer solution; (b) selectivity test of probe 1-D-fructose complex (probe 1, $2 \mu \mathrm{M}$; D-fructose, $100 \mathrm{mM}$ ) in the presence of various ROS/ RNS in pH 7.3 buffer solution. The spectra were collected with excitation at $410 \mathrm{~nm}$ at $25^{\circ} \mathrm{C}$ (Ex slit: 5.0, Em slit: 5.0).
$\mathrm{ONOO}^{-}(500 \mu \mathrm{M})$, the fluorescence ratio only slightly decreased to $\left(F-F_{0}\right) / F=c a$. 0.09 with $\mathrm{H}_{2} \mathrm{O}_{2}$, while the value decreased significantly to $\left(F-F_{0}\right) / F=c a$. 0.65 for $\mathrm{ONOO}^{-}$. Therefore, our fluorescent probe can be employed for the selective and sensitive detection of peroxynitrite under physiological and pathological conditions where ${ }^{-} \mathrm{OCl}$ is not present or is at very low concentration. In addition, previous research reported that endogenous amines and thiols readily react with hypochlorite, ${ }^{37}$ which makes it unlikely that hypochlorite will compete with peroxynitrite for the boronate-based fluorescence probes in the cellular system.

\section{Intracellular imaging for exogenous and endogenous $\mathrm{ONOO}^{-}$}

We then evaluated the ability of the probe 1-D-fructose complex to visualize exogenous and endogenous $\mathrm{ONOO}^{-}$using cell imaging experiments. The HeLa cells were incubated with probe $1(5 \mu \mathrm{M})$ and $\mathrm{D}$-fructose $(250 \mathrm{mM})$ for $30 \mathrm{~min}$ at $37{ }^{\circ} \mathrm{C}$, after which we added $0 \mu \mathrm{M}, 5 \mu \mathrm{M}$ and $30 \mu \mathrm{M}$ peroxynitrite-PBS buffer solutions for $10 \mathrm{~min}$ at $37^{\circ} \mathrm{C}$, and after washing with DPBS, the cells were observed using confocal laser scanning microscopy. The probe 1-D-fructose complex can penetrate into the live cell membrane and displayed strong fluorescence throughout the cytoplasm region (Fig. 5A(b)). When external peroxynitrites were
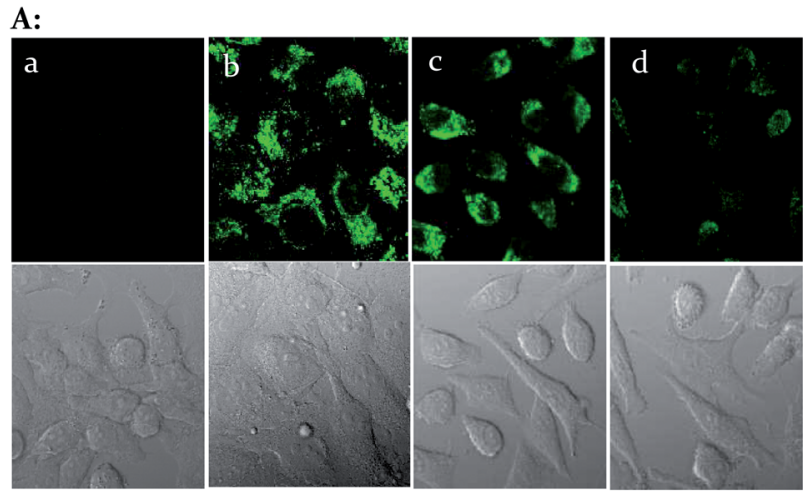

B:
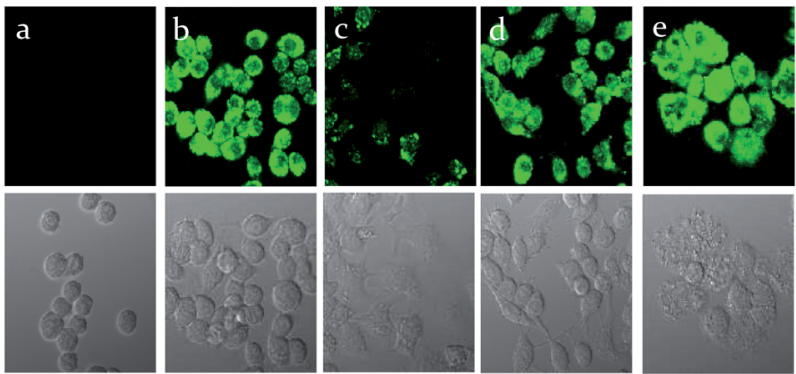

Fig. 5 (A) Fluorescent imaging for exogenous $\mathrm{ONOO}^{-}$in HeLa cells. The probe 1-D-fructose was formed by mixing probe $1(5 \mu \mathrm{M})$ and $D-$ fructose $(250 \mathrm{mM})$ in situ. (a) Blank without probe; (b) probe 1-Dfructose only; (c) probe 1-D-fructose and $\mathrm{ONOO}^{-}(5 \mu \mathrm{M})$; (d) probe 1$\mathrm{D}$-fructose and $\mathrm{ONOO}^{-}(30 \mu \mathrm{M})$. (B) Fluorescent imaging for endogenous $\mathrm{ONOO}^{-}$in RAW 264.7 cells. The probe 1-D-fructose was formed by mixing probe $1(5 \mu \mathrm{M})$ and $\mathrm{D}$-fructose $(250 \mathrm{mM})$ in situ. (a) Blank without probe; (b) probe 1-D-fructose only; (c) probe 1-Dfructose and LPS, IFN- $\gamma$, PMA; (d) c + aminoguanidine; (e) c + TEMPO. 
added to the cells, the fluorescence of the probe 1-D-fructose complex was quenched in a concentration-dependent manner (Fig. 5A(c) and $\mathrm{A}(\mathrm{d})$ ).

Animal macrophage cell lines can produce peroxynitrite via immunogenic stimuli. ${ }^{41}$ Therefore, to detect peroxynitrite made naturally in the cell, we used RAW 264.7 cells (mouse macrophage). RAW 264.7 cells were stimulated with $1 \mu \mathrm{g} \mathrm{ml}{ }^{-1}$ LPS (lipopolysaccharide, bacterial membrane component) for $16 \mathrm{~h}$ at $37{ }^{\circ} \mathrm{C}, 50 \mathrm{ng} \mathrm{ml}{ }^{-1} \mathrm{IFN}-\gamma$ for $4 \mathrm{~h}$ and $2.5 \mathrm{ng} \mathrm{ml}{ }^{-1}$ PMA for 30 min, and then incubated with $5 \mu \mathrm{M}$ sensor for $30 \mathrm{~min}$. They showed weak fluorescence compared to control cells (Fig. 5B(b) and $\mathrm{B}(\mathrm{c})$ ). For the inhibition test of peroxynitrite production, $100 \mu \mathrm{M}$ TEMPO (superoxide scavenger) and $0.5 \mathrm{mM}$ amino guanidine (nitric oxide synthase inhibitor) were pretreated with the media for $4 \mathrm{~h}$ and in this case strong fluorescence was observed (Fig. 5B(d) and $\mathrm{B}(\mathrm{e})$ ). From these experiments, it is clear that the reaction of the sensor with peroxynitrite can be detected in live cells.

\section{Conclusions}

In conclusion, we have developed a new approach for the intracellular detection of $\mathrm{ONOO}^{-}$through the use of a boronic acid fluorescent probe in the presence of monosaccharide (e.g. $\mathrm{D}$-fructose). The reaction between peroxynitrite and the boronic ester triggered a significant fluorescence on-off response which is selective over a variety of reactive oxygen and nitrogen species. Notably, from the perspective of a mechanistic explanation, the enhanced interaction between the amine and the boron provides a novel strategy to design new fluorescent probes for the detection of peroxynitrite which can distinguish $\mathrm{ONOO}^{-}$from $\mathrm{H}_{2} \mathrm{O}_{2}$ and other ROS/RNS. More importantly, the simple, sensitive fluorescent probe was successfully manipulated to visualize exogenous and endogenous $\mathrm{ONOO}^{-}$in living cells. We believe that our novel system will enable the investigation of diseases states (such as inflammation) in biological systems involving the production of peroxynitrite..$^{2,42,43}$

\section{Methods}

\section{Experimental methods}

In the corresponding experiments, in vitro fluorescence titrations with peroxynitrite and other ROS/RNS were carried out at $25{ }^{\circ} \mathrm{C}$ in $\mathrm{pH} 7.30 \mathrm{PBS}$ buffer $\left(\mathrm{KH}_{2} \mathrm{PO}_{4}, 1 / 15 \mathrm{M} ; \mathrm{Na}_{2} \mathrm{HPO}_{4}, 1 / 15 \mathrm{M}\right)$ and $\mathrm{pH} 5.00$ buffer (NaOAc-HOAc, $50 \mathrm{mM}$ ). The saccharideboronic acid complexes were formed by mixing free boronic acid $(2 \mu \mathrm{M})$ with D-fructose $(100 \mathrm{mM})$ for $10 \mathrm{~min}$ in situ. The peroxynitrite alkaline stock was prepared following a literature procedure $^{\mathbf{4 4}}$ and assayed using a UV-Vis spectrophotometer via $\varepsilon_{302 \mathrm{~nm}}=1670 \mathrm{~cm}^{-1} \mathrm{M}^{-1}$. The preparation of other ROS and RNS solutions is described in the $\operatorname{ESI}_{\dagger} \dagger$ (General methods).

\section{Confocal microscopy imaging}

Cells were seeded in $35 \mathrm{~mm}$ glass bottomed dishes at a density of $3 \times 10^{5}$ cells per dish in culture media. After $24 \mathrm{~h}, 5 \mu \mathrm{M}$ sensor (final $0.25 \% \mathrm{DMF}, \mathrm{N}, \mathrm{N}$-dimethylformamide) and 250
$\mathrm{mM}$ D-fructose were added to the cells and the cells were incubated for $30 \mathrm{~min}$ at $37^{\circ} \mathrm{C}$. For HeLa cells, the 5 or $30 \mu \mathrm{M}$ peroxynitrite-PBS solutions were added to the cells for $10 \mathrm{~min}$ at 37 ${ }^{\circ} \mathrm{C}$. For RAW 264.7 cells, $1 \mu \mathrm{g} \mathrm{ml}{ }^{-1}$ LPS (lipopolysaccharide) was added to the media for $16 \mathrm{~h}, 50 \mathrm{ng} \mathrm{ml}{ }^{-1} \mathrm{IFN}-\gamma$ (interferongamma) for $4 \mathrm{~h}$ and $2.5 \mathrm{ng} \mathrm{ml^{-1 }}$ PMA (phorbol 12-myristate-13acetate) for $30 \mathrm{~min}$, and the cells were then incubated with $5 \mu \mathrm{M}$ sensor for $30 \mathrm{~min}$. For the inhibition test, $100 \mu \mathrm{M}$ TEMPO and $0.5 \mathrm{mM}$ amino guanidine were added to the media for $4 \mathrm{~h}$. After washing with the DPBS twice to remove the residual probe, the cells were imaged by confocal laser scanning microscopy (FV1200, Olympus, Japan). Cells were excited by a $405 \mathrm{~nm}$ diode laser and detected at BA 490-590 $\mathrm{nm}$.

\section{Acknowledgements}

TDJ and XS are grateful for financial support from China Scholarship Council (CSC) and University of Bath Full Fees Scholarship. The Catalysis And Sensing for our Environment (CASE) network is thanked for research exchange opportunities. JSF, SDB and TDJ thank ECUST for guest professorships. JSF thanks the University of Birmingham for support. JY thanks the support from the National Research Foundation of Korea (NRF) grants funded by the Korean government (MSIP) (no. 2012R1A3A2048814).

\section{Notes and references}

1 J. S. Beckman, T. W. Beckman, J. Chen, P. A. Marshall and B. A. Freeman, Proc. Natl. Acad. Sci. U. S. A., 1990, 87, 1620.

2 P. Pacher, J. S. Beckman and L. Liaudet, Physiol. Rev., 2007, 87, 315.

3 K.-T. Lin, J.-Y. Xue, M. C. Lin, E. G. Spokas, F. F. Sun and P. Y.-K. Wong, Am. J. Physiol.: Cell Physiol., 1998, 274, C855.

4 A. G. Estévez, R. Radi, L. Barbeito, J. T. Shin, J. A. Thompson and J. S. Beckman, J. Neurochem., 1995, 65, 1543.

5 C. Szabo, H. Ischiropoulos and R. Radi, Nat. Rev. Drug Discovery, 2007, 6, 662.

$6 \mathrm{H}$. Ischiropoulos and J. S. Beckman, J. Clin. Invest., 2003, 111, 163.

7 P. Sarchielli, F. Galli, A. Floridi, A. Floridi and V. Gallai, Amino Acids, 2003, 25, 427.

8 F. Torreilles, S. d. Salman-Tabcheh, M.-C. Guérin and J. Torreilles, Brain Res. Rev., 1999, 30, 153.

9 N. Ito, U. T. Ruegg, A. Kudo, Y. Miyagoe-Suzuki and S. i. Takeda, Nat. Med., 2013, 19, 101.

10 X. Chen, X. Tian, I. Shin and J. Yoon, Chem. Soc. Rev., 2011, 40, 4783.

11 D. Yang, H.-L. Wang, Z.-N. Sun, N.-W. Chung and J.-G. Shen, J. Am. Chem. Soc., 2006, 128, 6004.

12 Z.-N. Sun, H.-L. Wang, F.-Q. Liu, Y. Chen, P. K. H. Tam and D. Yang, Org. Lett., 2009, 11, 1887.

13 T. Peng and D. Yang, Org. Lett., 2010, 12, 4932.

14 Q. Zhang, Z. Zhu, Y. Zheng, J. Cheng, N. Zhang, Y. T. Long, J. Zheng, X. Qian and Y. Yang, J. Am. Chem. Soc., 2012, 134, 18479.

15 Z. J. Chen, W. Ren, Q. E. Wright and H. W. Ai, J. Am. Chem. Soc., 2013, 135, 14940. 
16 E. Galbraith and T. D. James, Chem. Soc. Rev., 2010, 39, 3831. 17 R. Nishiyabu, Y. Kubo, T. D. James and J. S. Fossey, Chem. Commun., 2011, 47, 1106.

18 S. D. Bull, M. G. Davidson, J. M. van den Elsen, J. S. Fossey, A. T. Jenkins, Y. B. Jiang, Y. Kubo, F. Marken, K. Sakurai, J. Zhao and T. D. James, Acc. Chem. Res., 2013, 46, 312 .

19 X. Sun, S.-Y. Xu, S. E. Flower, J. S. Fossey, X. Qian and T. D. James, Chem. Commun., 2013, 49, 8311.

20 M. C. Y. Chang, A. Pralle, E. Y. Isacoff and C. J. Chang, J. Am. Chem. Soc., 2004, 126, 15392.

21 A. E. Albers, V. S. Okreglak and C. J. Chang, J. Am. Chem. Soc., 2006, 128, 9640.

22 E. W. Miller, O. Tulyathan, E. Y. Isacoff and C. J. Chang, Nat. Chem. Biol., 2007, 3, 263.

23 D. Srikun, E. W. Miller, D. W. Domaille and C. J. Chang, J. Am. Chem. Soc., 2008, 130, 4596.

24 G. C. Van de Bittner, E. A. Dubikovskaya, C. R. Bertozzi and C. J. Chang, Proc. Natl. Acad. Sci. U. S. A., 2010, 107, 21316.

25 D. Srikun, A. E. Albers, C. I. Nam, A. T. Iavarone and C. J. Chang, J. Am. Chem. Soc., 2010, 132, 4455.

26 B. C. Dickinson, C. Huynh and C. J. Chang, J. Am. Chem. Soc., 2010, 132, 5906.

27 E. W. Miller, A. E. Albers, A. Pralle, E. Y. Isacoff and C. J. Chang, J. Am. Chem. Soc., 2005, 127, 16652.

28 G. C. Van de Bittner, C. R. Bertozzi and C. J. Chang, J. Am. Chem. Soc., 2013, 135, 1783.

29 B. C. Dickinson, Y. Tang, Z. Chang and C. J. Chang, Chem. Biol., 2011, 18, 943.

30 A. R. Lippert, G. C. Van de Bittner and C. J. Chang, Acc. Chem. Res., 2011, 44, 793.
31 S. Banerjee, E. B. Veale, C. M. Phelan, S. A. Murphy, G. M. Tocci, L. J. Gillespie, D. O. Frimannsson, J. M. Kelly and T. Gunnlaugsson, Chem. Soc. Rev., 2013, 42, 1601.

32 R. M. Duke, E. B. Veale, F. M. Pfeffer, P. E. Kruger and T. Gunnlaugsson, Chem. Soc. Rev., 2010, 39, 3936.

33 S. Banerjee, J. A. Kitchen, S. A. Bright, J. E. O'Brien, D. C. Williams, J. M. Kelly and T. Gunnlaugsson, Chem. Commun., 2013, 49, 8522.

34 R. B. P. Elmes, M. Erby, S. A. Bright, D. C. Williams and T. Gunnlaugsson, Chem. Commun., 2012, 48, 2588.

35 L. Zhu, S. H. Shabbir, M. Gray, V. M. Lynch, S. Sorey and E. V. Anslyn, J. Am. Chem. Soc., 2006, 128, 1222.

36 J. Zielonka, A. Sikora, M. Hardy, J. Joseph, B. P. Dranka and B. Kalyanaraman, Chem. Res. Toxicol., 2012, 25, 1793.

37 A. Sikora, J. Zielonka, M. Lopez, J. Joseph and B. Kalyanaraman, Free Radical Biol. Med., 2009, 47, 1401.

38 Q. Xu, K.-A. Lee, S. Lee, K. M. Lee, W.-J. Lee and J. Yoon, J. Am. Chem. Soc., 2013, 135, 9944.

39 S. Trupp, A. Schweitzer and G. J. Mohr, Org. Biomol. Chem., 2006, 4, 2965.

40 T. D. James, K. R. A. S. Sandanayake, R. Iguchi and S. Shinkai, J. Am. Chem. Soc., 1995, 117, 8982.

41 M. Pekarova, L. Kubala, H. Martiskova, L. Bino, M. Twarogova, A. Klinke, T. K. Rudolph, Z. Kuchtova, H. Kolarova, G. Ambrozova, R. Kuchta, J. Kadlec and A. Lojek, Eur. J. Pharmacol., 2013, 713, 68.

42 S. Pfeiffer, A. Lass, K. Schmidt and B. Mayer, FASEB J., 2001, 15, 2355.

43 J. C. Sullivan and J. S. Pollock, Circ. Res., 2006, 98, 717.

44 J. W. Reed, H. H. Ho and W. L. Jolly, J. Am. Chem. Soc., 1974, 96, 1248. 